\title{
Down-regulation of Arabidopsis DND1 orthologs in potato and tomato leads to broad-spectrum resistance to late blight and powdery mildew
}

\author{
Kaile Sun • Anne-Marie A. Wolters • Annelies E. H. M. Loonen • Robin P. Huibers • \\ René van der Vlugt • Aska Goverse • Evert Jacobsen • \\ Richard G. F. Visser $\cdot$ Yuling Bai
}

Received: 11 June 2015/Accepted: 7 November 2015/Published online: 17 November 2015

(C) The Author(s) 2015. This article is published with open access at Springerlink.com

\begin{abstract}
Multiple susceptibility genes (S), identified in Arabidopsis, have been shown to be functionally conserved in crop plants. Mutations in these $S$ genes result in resistance to different pathogens, opening a new way to achieve plant disease resistance. The aim of this study was to investigate the role of Defense No Death 1 (DND1) in susceptibility of tomato and potato to late blight (Phytophthora infestans). In Arabidopsis, the $d n d l$ mutant has broad-spectrum resistance against several fungal, bacterial, and viral pathogens. However this mutation is also associated with a dwarfed phenotype. Using an RNAi approach, we silenced
\end{abstract}

Electronic supplementary material The online version of this article (doi:10.1007/s11248-015-9921-5) contains supplementary material, which is available to authorized users.

K. Sun · A.-M. A. Wolters · A. E. H. M. Loonen ·

R. P. Huibers · E. Jacobsen · R. G. F. Visser .

Y. Bai $(\bowtie)$

Wageningen UR Plant Breeding, Wageningen University and Research Centre, Droevendaalsesteeg 1,

6708 PB Wageningen, The Netherlands

e-mail: bai.yuling@wur.nl

R. van der Vlugt

Laboratory of Virology, Wageningen University and

Research Centre, Droevendaalsesteeg 1,

6708 PB Wageningen, The Netherlands

\section{A. Goverse}

Laboratory of Nematology, Wageningen University and

Research Centre, Droevendaalsesteeg 1,

6708 PB Wageningen, The Netherlands
AtDND1 orthologs in potato and tomato. Our results showed that silencing of the DND1 ortholog in both crops resulted in resistance to the pathogenic oomycete $P$. infestans and to two powdery mildew species, Oidium neolycopersici and Golovinomyces orontii. The resistance to $P$. infestans in potato was effective to four different isolates although the level of resistance (complete or partial) was dependent on the aggressiveness of the isolate. In tomato, DNDI-silenced plants showed a severe dwarf phenotype and autonecrosis, whereas DND1-silenced potato plants were not dwarfed and showed a less pronounced autonecrosis. Our results indicate that $S$ gene function of $D N D 1$ is conserved in tomato and potato. We discuss the possibilities of using RNAi silencing or loss-offunction mutations of DND1 orthologs, as well as additional $S$ gene orthologs from Arabidopsis, to breed for resistance to pathogens in crop plants.

Keywords Late blight - Powdery mildew .

Resistance $\cdot$ RNAi $\cdot$ Susceptibility $(S)$ gene $\cdot$ DND1

\section{Introduction}

Potato and tomato are important food crops that are grown worldwide. Diseases such as powdery mildew and late blight, cause substantial economic losses in these crops. Potato late blight, which is caused by the oomycete Phytophthora infestans, has been the most 
devastating potato disease over 150 years (Fry and Goodwin 1997; Haverkort et al. 2008). Currently, the most effective way of controlling the damage by $P$. infestans is by regular application of fungicide to protect both the infected foliage and tubers. The frequent fungicide applications not only raises environmental concerns, but also gives rise to fungicideresistant strains of $P$. infestans (Altamiranda et al. 2008; Eschen-Lippold et al. 2010; Bengtsson et al. 2013).

The most common method of resistance breeding to late blight is the introgression of major resistance genes $(R)$. After the massive outbreak of late blight in the $1850 \mathrm{~s}$ in potato, efforts to detect $R$ genes have been made in the twentieth century. This resulted in identification and use of a number of $R$ genes (NBSLRR genes e.g. $R 1, R 2, R 3$, and R10) from the Mexican wild species Solanum demissum (Malcolmson 1969; Wastie 1991). The introgression of $R$ genes into cultivated potato species through interspecific crosses and backcrosses can be time consuming and associated with linkage drag (Schouten et al. 2006). Resistance mediated by $R$ genes is frequently associated with a hypersensitive reaction (HR), as a result of the interaction between the $R$ gene and a specific avirulence gene of the pathogen (Lokossou et al. 2010). Due to new virulent races of $P$. infestans, introduced $R$ genes were rapidly overcome by the pathogen after only a few years in the field (Vleeshouwers et al. 2011). An option to achieve a broad spectrum, and more durable resistance, is to stack $R$ genes against many isolates (Kim and Hwang 2012; Zhu et al. 2012). In recent years, additional late blight $R$ genes have been identified and cloned from other Solanum species, including $S$. bulbocastanum, $S$. stoloniferum, S. venturii, S. mochiquense, and $S$. chacoense (Vossen et al. 2011). The cloning and pyramiding of these $R$ genes is facilitated by the availability of genome sequences for potato and tomato as well as information on $P$. infestans effectors (Jo et al. 2011; Vleeshouwers et al. 2011; Gebhardt 2013). Also, rotation of potato cultivars carrying different $R$ genes is a good option to extend the effectivity of resistance conferred by $R$ genes in the field.

Supplementary to the use of $R$ genes, in 2010 we proposed a novel breeding strategy based on "loss-offunction of susceptibility genes" for durable and broad-spectrum resistance (Pavan et al. 2010). Plant genes coding for susceptibility factors are named susceptibility genes ( $S$ genes), which can be functionally divided into immunity-related and immunityunrelated groups (Hückelhoven et al. 2013). Immunity-related $S$ genes play a role in plant defence responses, while immunity-unrelated genes provide entrance, accommodation and nutrients for pathogens. In a recent review (Van Schie and Takken 2014), $S$ genes were divided into three groups based on the time of their action. The first group ( $S$ gene allowing basic compatibility) includes those that provide early pathogen establishment, such as the Mildew resistance Locus $O(M L O)$ gene, encoding a membrane-anchored protein (Büschges et al. 1997) that is required for susceptibility to powdery mildews. The second group ( $S$ genes encoding immune suppressors) contains those that interfere negatively with host defense responses such as the Cellulose synthase 3 (CESA3) gene. The CESA3 (cevl) mutant shows constitutively activated JA and ethylene defence signalling pathways. The third group ( $S$ genes allowing sustained compatibility) covers those involved in feeding of the pathogen, such as the rice $X a 13$ and $X a 25$ genes. These two genes encode sugar transporters providing nutrients to the pathogen, Xanthomonas oryzae (Chen et al. 2010).

From a genetic point of view, we consider a gene as an $S$ gene, when impairment of its function can lead to recessively inherited resistance (Pavan et al. 2010). In Arabidopsis, many loss-of-function mutations are known to cause pathogen resistance. Examples are powdery mildew resistance ( $p m r$; Vogel and Somerville 2000; Vogel et al. 2002) and downy mildew resistance mutants (dmr to Hyaloperonospora parasitica; McDowell et al. 2005). However, only few $S$ genes have been tested for their conserved function in crops. The best-studied example is the Mlo gene. Mutations in certain Mlo homologs in plant species (e.g. barley Mlo, Arabidopsis AtMlo2, pea PsMlo1 and tomato SlMlo1) result in disease resistance by preventing the penetration of the adapted powdery mildew species (e.g. Bai et al. 2008; Pavan et al. 2011; Zheng et al. 2013). The first identified barley mlo mutant has been successfully used in barley cultivars in European agriculture for more than 35 years, illustrating the durability of mlo-based resistance (Lyngkjaer et al. 2000; Humphry et al. 2006).

Our research is aimed at identifying $S$ genes for susceptibility to different pathogens in tomato and 
potato. We have tested the susceptibility function of several $S$ genes identified in Arabidopsis and demonstrated that in tomato, silencing $P M R$ and $D M R$ orthologs gives rise to resistance against the mildew fungus Oidium neolycopersici (Huibers et al. 2013). Our results suggest that $S$ genes such as $M L O, P M R$ and $D M R$ genes are functionally conserved among plant species and that silencing orthologs in other plant species can give resistance to fungi. In this study, we focused on the Arabidopsis AtDND1 (Defense No Death 1) gene (Yu et al. 1998) encoding a cyclic nucleotide-gated cation channel (CNGC; also known as AtCNGC2, Clough et al. 2000). In Arabidopsis, dndl mutants were reported to show resistance to Pseudomonas syringae and other fungal and viral pathogens ( $\mathrm{Yu}$ et al. 2000; Jurkowski et al. 2004; Genger et al. 2008). Here, we show that silencing tomato and potato DND1 orthologs resulted in resistance to both late blight and powdery mildew.

\section{Materials and methods}

Plant growth and cultivation

Tomato (S. lycopersicum cultivar Moneymaker, MM), tetraploid potato $S$. tuberosum cultivar Desiree, diploid potato genotype SH83-92-488 (SH) (Rouppe van der Voort et al. 1997) and potato transformant A13-013 carrying the Rpi-vnt1.1 resistance gene in Desiree background (Foster et al. 2009; Pel et al. 2009) were used. Plants were grown in greenhouses at 21 and $19{ }^{\circ} \mathrm{C}$ during the $16 \mathrm{~h}$ day and $8 \mathrm{~h}$ night periods respectively. Relative humidity was $70 \%$ and light intensity was supplemented with $100 \mathrm{~W} / \mathrm{m}^{2}$ when light intensity dropped below $150 \mathrm{~W} / \mathrm{m}^{2}$. Potato transgenic plants were also grown in large 5-1 pots in an insect-free screen cage on a concrete floor under outdoor summer conditions. All transgenic plants were grown with a GMO permit according to Dutch GMO regulations.

Identification of tomato and potato DND1 orthologs

The Arabidopsis thaliana DND1 (GenBank accession number BAE99132) amino acid sequence was used as a query in a BLASTP program against the Sol Genomics Network (SGN) Tomato Genome protein sequences (ITAG release 2.40) or Potato PGSC DM v3.4 protein sequences database (http://solgenomics. net/tools/blast/) or against an Arabidopsis protein database (http://www.arabidopsis.org/Blast/index.jsp) to search for homologous sequences in tomato, potato and Arabidopsis, respectively. The alignment of the protein sequences was done by DNASTAR Lasergene 8 and phylogenetic trees were constructed by using Mega4.0 (Tamura et al. 2007). The evolutionary history was inferred using the neighbour-joining method (Saitou and Nei 1987). The percentage of replicate trees in which the associated taxa clustered together in the bootstrap test $(10,000$ replicates) is shown next to the branches.

Generation of RNAi transgenic plants

The binary vector pHellsgate 8 (CSIRO, Australia) was used to generate RNAi constructs (Waterhouse and Helliwell 2003; Helliwell and Waterhouse 2003) with a CaMV35S promoter and containing a kanamycin resistance gene as selectable marker. Primers were designed to amplify fragments of the target genes ranging from 150 to $300 \mathrm{bp}$ (Supplementary Table 1). The forward primer contained CACC at the $5^{\prime}$ end for TOPO cloning. Tomato MM cDNA was used as PCR template. The PCR products were cloned into the pENTR/D-TOPO cloning vector (Invitrogen, USA) and were sequenced. The final RNAi vector was produced by an LR clonase reaction between the entry clone and pHellsgate8 vectors. Transformation of MM seeds was carried out as described by Huibers et al. (2013). For potato transformation the protocol described by Visser (1991) was used.

Nucleic acid extraction and RNA expression analyses

Nucleic acid extraction was carried out as described by Huibers et al. (2013). Quantitive real-time PCR (qRTPCR) was performed to determine the expression levels of potato and tomato $D N D 1$ in different tissues without pathogen stress conditions. Tomato RNA samples were isolated from 12-week-old MM plants grown in the greenhouse. Potato samples were isolated from 8-week-old Desiree plants from the field. The qPCR was performed in triplicate with a C1000 light cycler system (Bio-Rad) using SYBR Green mix (Bio$\mathrm{Rad})$ with gene-specific primers for DND1 
(Supplementary Table 1). qRT-PCR data for DND1 were compared with RNAseq data from potato and tomato. Potato FPKM values for Sotub02g034 320 were obtained from the Spud DB website (http://solanaceae.plantbiology.msu.edu/index.shtml). Tomato RPKM values for Solyc02g088560 were obtained from http://ted.bti.cornell.edu/cgi-bin/TFGD/ digital/home.cgi using library D004: Transcriptome analysis of various tissues in tomato cultivar Heinz and the wild relative Solanum pimpinellifolium.

The expression level of StPRI (GenBank AJ250136) in Desiree and transgenic potato plants was analyzed by qRT-PCR with RNA samples isolated from 6-week-old plants grown in the greenhouse. In addition, StPRl expression was analyzed in selected transgenic plants compared with wild type Desiree after mock inoculation or inoculation of 6-week-old plants grown in the greenhouse with $P$. infestans isolate Pic99189. Gene-specific primers are shown in Supplementary Table 1. Relative quantification was performed by qRT-PCR using the $\Delta \Delta \mathrm{Ct}$ method (Livak and Schmittgen 2001). The potato and tomato elongation factor 1-a (EF1a, Sotub06g010680 and Solyc06g005060) transcripts were used as the internal control to calculate the relative transcript levels. The gene-specific primers used for development of RNAi constructs, qPCR, and $O$. neolycopersici quantification are shown in Supplementary Table 1. For the qRT-PCR assays, three technical replicates were performed for each experiment and the expression of each gene was investigated in three biological replicates.

Disease assays

For detached leaf assays (DLA, Vleeshouwers et al. 1999) with $P$. infestans, several isolates were used. Information on virulence factors, mating type and data concerning the collection of $P$. infestans isolates is presented in Supplementary Table 2 . These isolates were cultured on rye sucrose medium (Caten and Jinks 1968) in the dark at $15{ }^{\circ} \mathrm{C}$ for 10-14 days. Sporulating mycelium was flooded with cold water and the sporangiospore suspension was incubated at $4{ }^{\circ} \mathrm{C}$ for $1-2 \mathrm{~h}$. The inoculum was adjusted to a concentration of $5 \times 10^{4}$ zoospores $/ \mathrm{ml}$. Potato leaves were taken from plants grown in the greenhouse. The lesion size on leaflets was measured using a calliper with digital display (DIGI-MET ${ }^{\circledR}$, Helios Preisser, Germany) at 3-6 days after inoculation. For potato tuber assays, the protocol described in Zhu et al. (2012) was applied. Tubers were taken from both greenhouse and screen cagegrown plants. Two assays with greenhouse tubers, and one assay with screen cage tubers were performed. For each transformant, four plants were tested as biological replicates.

For the test with tomato powdery mildew, the Wageningen isolate of Oidium neolycopersici, On-Ne (Bai et al. 2005) was used which has been maintained on plants of MM. Spore suspensions were obtained by washing heavily infected MM leaves in water. Tomato plants of about 4 weeks old were sprayed with an inoculum of $2.5 \times 10^{4}$ spores per ml. Fungal quantification by qPCR was performed on leaf samples collected between 8 and 14 days post inoculation (dpi). Oidium Internal Transcribed Spacer (ITS)specific primers (Huibers et al. 2013) are shown in Supplementary Table 1 .

For the nematode test, Globodera rostochiensis line 19 (the Ro1 pathotype) was used. Potato plants were obtained from sprouting tubers in sterile clay pots covered with sterile sandy soil. Four to five weeks after tuber planting the rooting plants were inoculated with the nematodes. To collect the eggs from the cysts, the cysts were soaked overnight in water. Then the cysts were crushed with a special glass pestle. After that, the suspension was filtered over a $100 \mu \mathrm{m}$ sieve. The final number of eggs for inoculation was around 10,000 eggs per pot. The cysts were extracted from roots 6 weeks post inoculation and counted by following the protocol described in Van Bezooijen (2006).

For disease test with potato virus Y (PVY), the $P V Y^{N T N}$ strain (isolate PRI-757) was used which was maintained in tobacco plants, Nicotiana tabacum cultivar Samsun. Potato transformants were regenerated from in vitro plantlets and grown in the greenhouse in soil under controlled environmental conditions (16/8 light/dark cycle, $24{ }^{\circ} \mathrm{C}$ ) for 4 weeks before $P V Y$ inoculation. Three newly developed upper leaves were dusted with carborundum powder and rubbed with cheesecloth dipped in a sap prepared from the leaves of the $P V Y$-infected tobacco plants. After $10 \mathrm{~min}$, the leaves were washed liberally with tap water. In mock inoculations, water was used instead of the sap. The presence of $P V Y^{N T N}$ in plants was monitored using a polyclonal rabbit antiserum, raised against purified virus, in a double antibody sandwich (DAS) enzyme-linked immuno-absorbent assay (ELISA) (Van den Heuvel and Peters 1989). All 
plants, both the inoculated plants and the mock noninoculated plants were checked for the presence or absence of virus 14 dpi by DAS-ELISA. Each treatment had four plants as biological replicates.

\section{Pathogen identification}

To verify the identity of powdery mildew species affecting potato in the greenhouse, DNA was extracted from powdery mildew infected leaves using DNeasy ${ }^{\circledR}$ Plant Mini Kit (QIAGEN, Germany). Fungal ITS primers, ITS5A (5'-TTGGAAGTAAAAGTCGTA AC-3', derived from ITS5) and ITS4 (5'-TCCTC CGCTTATTGATAGC- $3^{\prime}$ ) were used (White et al. 1990). The PCR products were sequenced and blasted against the NCBI database (http://www.nibi.nlm.nih. gov/BLAST/).

Time lapse video

A time lapse video was produced to visualize $P$. infestans development on leaves of wild type potato Desiree and transgenic RNAi::DND1A plants. A $12-\mathrm{cm}$ square Petri dish was filled with autoclaved demineralized water containing $1 \%$ agar to a thickness of $5 \mathrm{~mm}$. Detached potato leaflets were transferred into the Petri dish and kept until the medium was solidified. Leaflets were taken from the same plants as those used in the DLA (see above). They were inoculated with P. infestans isolate Pic99189 zoospores using the same inoculum concentration as in the DLA $\left(5 \times 10^{4}\right.$ zoospores $\left./ \mathrm{ml}\right)$. Then, the Petri dish was sealed with Parafilm and placed in a closed box containing a Nikon D90 DSLR camera with a Nikon $60 \mathrm{~mm}$ lens. To achieve a $16 \mathrm{~h}$ light $/ 8 \mathrm{~h}$ dark cycle, the Petri dish was illuminated with Philips LED modules $(4 \times$ white, $2 \times$ blue and $2 \times$ deep red modules; light intensity $37.9 \mu \mathrm{E} \mathrm{m}^{-2} \mathrm{~s}^{-1}$ ) connected to a microprocessor (Arduino Uno) controlling the light. With the help of Nikon Camera Control Pro 2 software, photos were automatically taken once every $15 \mathrm{~min}$. The video is played back at 10 frames per second, and edited using Adobe Photoshop Lightroom 5 software. Depending on the growth conditions such as light and composition of the medium in this experiment, plants can be observed in the Time lapse system for up to 5 days.

\section{Results}

Identification of tomato and potato DND1 orthologs

Using BLAST analysis we identified a single tomato gene (Solyc02g088560) encoding a protein with a high level of amino acid identity (75\%) with AtDND1 (At5g15410), and hereafter referred to as SIDND1. In potato, a single gene was also identified (Sotub02g034320) encoding a protein having 75 and $99 \%$ identity with Arabidopsis AtDND1 or tomato SIDND1, respectively (Supplementary Fig. 1a), hereafter referred to as StDND1. In Arabidopsis there are 20 CNGC genes (Chin et al. 2013). In a protein-based phylogenetic tree SIDND1 and StDND1 showed higher homology to AtDND1 (CNGC2) than to any other Arabidopsis CNGC family member (Supplementary Fig. 1b). Therefore, SIDNDI and StDNDI are the most likely candidates for being AtDND1 orthologs.

Transcript levels of DND1 in various tissues of tomato and potato

Expression levels of DNDl were examined in leaf, root, flower, fruit (tomato only), and tuber (potato only) samples by quantitative real-time PCR. As shown in Supplementary Fig. 2, DND1 mRNA was detected in all tissues, but at different levels. The DND1 expression level was highest in flowers, more than 15-fold as high as that of the leaves. In contrast, DND1 transcripts were low in roots, tomato fruit or potato tubers (Supplementary Fig. 2a, b). These measured expression levels of DND1 correlated well with RNAseq data (RPKM or FPKM values) for tomato cultivar Heinz and potato genotype RH (Supplementary Figure 2c, d respectively).

StDND1 silenced potato plants are resistant to late blight

Two RNAi constructs (RNAi::DND1A and RNAi::DND1B) were made based on the tomato SIDND1 sequence (Supplementary Fig. 3a). These two constructs were designed to silence both tomato and potato DNDl orthologs (Supplementary Fig. 3b), with RNAi::DND1A targeting the $5^{\prime}$ part of the coding sequence and RNAi::DND1B targeting the $3^{\prime}$ end. 
Both RNAi constructs were used to transform potato cultivar Desiree, and in total 187 transgenic plants were obtained. For each RNAi construct, eight plants were randomly selected and the expression level of StDND1 was measured (Supplementary Fig. 3c). Compared with Desiree, the expression level of StDND1 in the transformants was reduced 10-90\%. Three transformants of each construct, DND1A-5, -8 -17 and DND1B-6, -8, -11, which had a high silencing level of StDND1 (well-silenced and indicated as + ) and a plant morphology and growth similar to wild type Desiree, were selected for further experiments. As negative controls, transformants with a low degree of silencing (indicated as -), DND1A-6 and DND1B-4, were selected and included in further analyses. The selected plants were multiplied by in vitro cuttings and tubers were harvested after growth of these cuttings in the greenhouse.

To assess the response of the selected plants to $P$. infestans infection, they were inoculated with the isolate Pic99189 in a DLA assay. The expression level of StDND1 was verified (Fig. 1a). Infection lesion diameter on infected leaves was determined daily from 3 to 6 dpi (Fig. 1b). The resistant control A13-013 carrying the Rpi-vnt1.1 gene showed no lesions during the whole period. In contrast, leaves of the susceptible control Desiree were almost fully covered by lateblight mycelia at $7 \mathrm{dpi}$. Three DND1A (+) transformants and two DND1B (+) transformants were as resistant as A13-013. Only DND1B-8(+) showed restricted lesion growth and a more variable level of StDND1 expression compared to the other $(+)$ transformants (Fig. 1a). Plants of the two DNDl weaksilenced (-) transformants were as susceptible as Desiree (Fig. 1c). Development of symptoms on detached leaves of Desiree and transformants DND1A-6(-), DND1A-5(+) and DND1A-17(+) is also shown in the time lapse movie Supplementary Video 1. The transformants in the DLA assay were also subjected to a tuber slice assay with $P$. infestans. Similar to the DLA results, tubers of the well-silenced transformants showed significantly lower levels of StDND1 expression (Fig. 2a) and almost no late blight sporulation compared to Desiree and the weaksilenced transformants (Fig. 2b).

For both DLA and tuber assays, three independent experiments were performed with similar results, demonstrating that the RNAi plants in which StDND1 is well silenced could lead to complete resistance to $P$. infestans isolate Pic99189 in both leaves and tubers. To analyse whether the resistance observed under greenhouse conditions was stable in other environmental conditions, a tuber slice assay was performed using tubers that developed on plants grown in a screen cage under outdoor conditions. Results obtained with these tubers (Supplementary Fig. 4) were similar to those from greenhouse-grown tubers (Fig. 2b).

StDND1 silenced potato plants show resistance to multiple isolates of late blight

In order to investigate whether StDNDI silenced potato plants show race non-specific resistance to $P$. infestans, the above tested RNAi transformants were challenged in a DLA assay with three additional $P$. infestans isolates; Pic99177, USA618 and EC\#1. Desiree was considered as the susceptible control and A13-013 as the resistant control for isolates Pic99177 and USA618. Both Desiree and A13-013 are susceptible to the aggressive isolate EC\#1. Development of lesion sizes on the infected leaves was determined from 3 to 7 dpi (Fig. 3). The experiment with the aggressive isolate EC\#1 was, however, terminated at 6 dpi because of serious disease symptoms. Similar to the results obtained with the isolate Pic99189, RNAi plants in which StDND1 is wellsilenced, showed resistance to isolates Pic99177 and USA618 (Fig. 3). With the aggressive isolate EC\#1 significantly smaller lesion sizes were observed for StDND1 well-silenced (+) transformants compared to Desiree and A13-013 (Fig. 3). In general, lesion growth on the susceptible plants (Desiree, A13-013 and non-silenced transformants) started from $3 \mathrm{dpi}$, while DND1A (+) and DND1B (+) transformants showed a delayed and restricted lesion growth starting from 4 dpi. These experiments were performed twice with similar results, showing that the acquired resistance by silencing of DND1 in potato is not specific to the tested isolates, though the resistance level may partially depend on the aggressiveness of the $P$. infestans isolates.

StDND1 silenced potato plants are resistant to powdery mildew

When potato plants are grown in the greenhouse they can be naturally infected by powdery mildew 

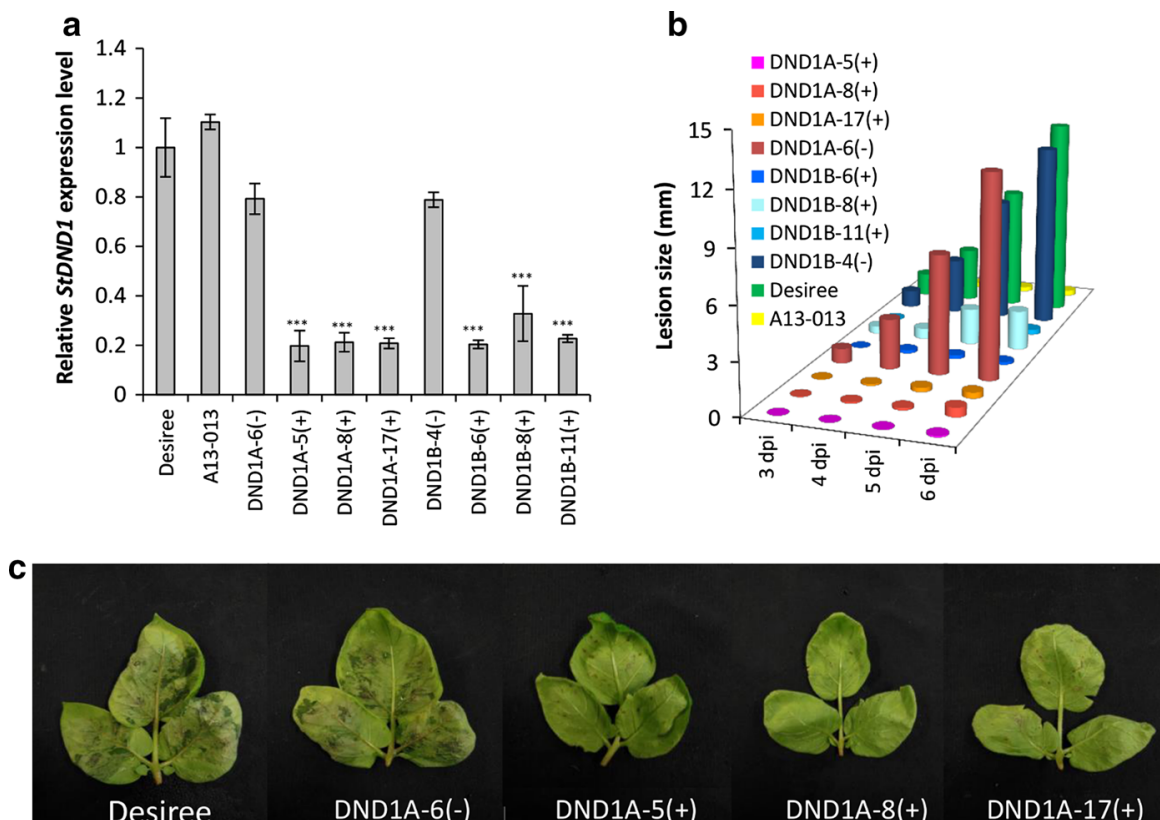

Desiree

DND1A-6(-)

DND1A-5(+)

DND1A-8(+)

DIA-17+
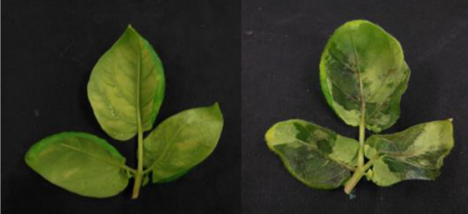

DND1B-4(-)

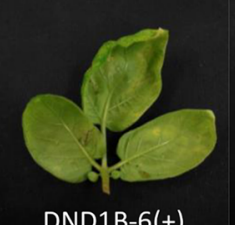

DND1B-6(+)

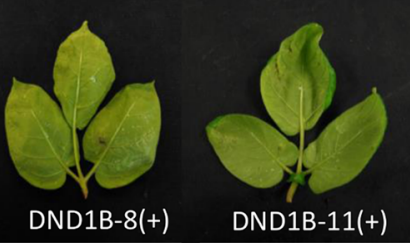

Fig. 1 Late blight resistance in potato leaves by silencing StDND1. a Relative expression level of StDND1 in leaves of Desiree, A13-013 and eight independent potato RNAi::DND1 plants (DND1A-5, 6, 8 and 17, DND1B-4, 6, 8 and 11). b Development of lesion size on plants infected with Phytophthora infestans isolate Pic99189. Data were collected at 3, 4, 5 and 6 days post inoculation (dpi). Well-silenced (+) plants

(Supplementary Fig. 5a). To verify the identity of the powdery mildew species infecting potato plants, DNA was isolated from infected potato leaves and used as a template for PCR amplification with fungal ITS (Internal Transcribed Spacer) primers (Supplementary Fig. 5b). The sequence amplified in this ITS region was identical to that of Golovinomyces orontii MUMH 2003 (GenBank AB427188, Uchida et al. 2009). Sporulation (characterised with a Disease Index (DI) score of about 2.5, Supplementary Fig. 5c) was observed on the upper side of older leaves of Desiree as well as on old leaves of the two weak-silenced transformants, DND1A-6(-) and DND1B-4(-). In contrast, no fungal sporulation (DI score of 0 , Supplementary Fig. 5c) was observed on leaves of well-silenced $(+)$ transformants. Natural infection showed significantly lower growth rate compared to untransformed Desiree and weak-silenced ( - ) plants. c Pictures of potato leaves taken at $7 \mathrm{dpi}$. Note the same plants were used for all the measurements. For each transformant, four plants were tested (one leaf per plant). Three independent experiments were performed with similar results

was uniform and plants were randomized. Fungal biomass was quantified (Supplementary Fig. 5d). All StDND1 silenced (+) plants showed significantly lower fungal biomass compared to the controls (Desiree and A13-013) and StDND1(-) plants.

Resistance by silencing of DND1 is specific to certain pathogens

To test whether $D N D 1$-silenced plants show resistance to a broad range of pathogens, StDND1 silenced potato plants were tested with nematode Globodera rostochiensis and potato virus Y $(P V Y)$. Compared with the susceptible control Desiree plants, all StDND1 silenced potato plants were susceptible to $P V Y$ (Supplementary Fig. 6). In the nematode test, diploid 


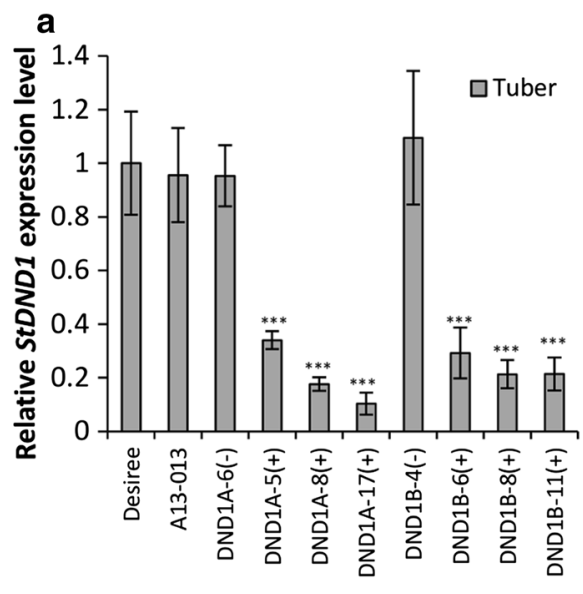

Fig. 2 Late blight resistance in potato tubers by silencing StDND1. a Relative expression level of StDND1 in tubers of Desiree, A13-013 and eight independent potato RNAi::DND1 plants (DND1A-5, 6, 8 and 17, DND1B-4, 6, 8 and 11).

potato genotype $\mathrm{SH}$ carrying the $H 1$ resistance gene was the resistant control. SH showed almost no cysts growing on the roots, while Desiree showed a high number of cysts (on average 250 per gram dry root weight (Supplementary Fig. 7). A lower number of cysts was observed on the well-silenced DND1 transformants. This reduction was however in general not significantly different from cyst number in Desiree.

Silencing of tomato SIDND1 results in powdery mildew and late blight resistance

Tomato plants of cultivar Moneymaker (MM) were transformed with RNAi::DND1A and the expression level of SIDNDI was measured in leaves of 5-weekold T1 plants. Among ten transformants, three T1 plants (T1\#2, \#5 and \#6) showed about $80 \%$ reduction of SIDND1 expression, compared to MM (Fig. 4a). These three independent SIDND1 silenced T1 transformants and untransformed MM were multiplied by cuttings. Ten cuttings of each T1 plant were inoculated with $O$. neolycopersici. To assess the disease severity, fungal biomass was measured. Compared with MM, significant lower amounts of fungal biomass were detected in these three $\mathrm{T} 1$ plants (Fig. 4b).

These $\mathrm{T} 1$ plants were maintained for seed production. Unfortunately, due to low male fertility of the T1 transformants, selfed progeny could only be obtained

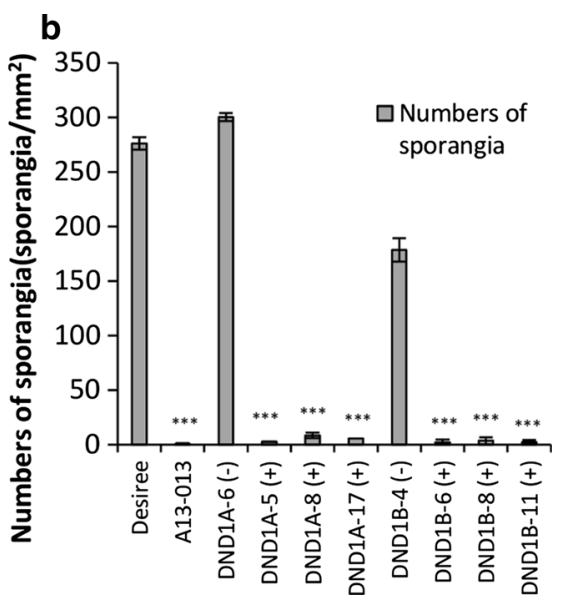

b Numbers of sporangia on tubers infected with Phytophthora infestans isolate Pic99189. For each transformant, four plants were tested (one tuber per plant). Asterisks indicate degree of significance compared to Desiree plants $(* * * p<0.001)$

from one T1 plant; T1\#2. The resulting T2 family (T2\#2) was inoculated with $O$. neolycopersici, and Disease Index (DI) was scored at $10 \mathrm{dpi}$. The T2\#2 plants harbouring a silencing construct $(+)$ showed significantly lower DI score compared to untransformed MM plants and T2\#2 plants not harbouring a silencing construct (-) (Fig. 4c). The same T2\#2 plants were tested by DLA with spores of $P$. infestans isolate Pic99177. A significant difference in DI scores at 6 dpi was observed between T2\#2 plants harbouring $(+)$ and not carrying (-) the silencing construct (Fig. 4d). Thus, silencing of SIDND1 in tomato resulted in resistance to powdery mildew $(O$. neolycopersici) and $P$. infestans showing agreement with the results obtained in potato.

Silencing of DND1 leads to side effects

Strong RNAi silencing of SIDND1 in tomato, resulted in two phenotypic side effects, dwarfing and necrosis (Fig. 5a). Autonecrosis (spontaneous cell death without pathogen infection) was observed on non-inoculated leaves of tomato transformants. Autonecrosis was also found on leaves of StDND1-silenced potato plants (Fig. 5b) However, it was much less severe than that in the tomato SIDND1-silenced transformants. In tomato, necrotic spots were present on both old and young leaves, while in potato necrosis occurred only on older leaves at greenhouse conditions. When the 
Fig. 3 Broad spectrum resistance to late blight in potato by silencing StDND1. Graphs show the development of lesion size of infected leaves of different genotypes after inoculation with three Phytophthora infestans isolates Pic99177, USA618 and EC\#1. Cuttings from the same transformants as in Figs. 1 and 2 were used. For each transformant, four plants were used. From each plant, three leaves were detached and each was inoculated with one isolate. The experiment was repeated twice with similar results

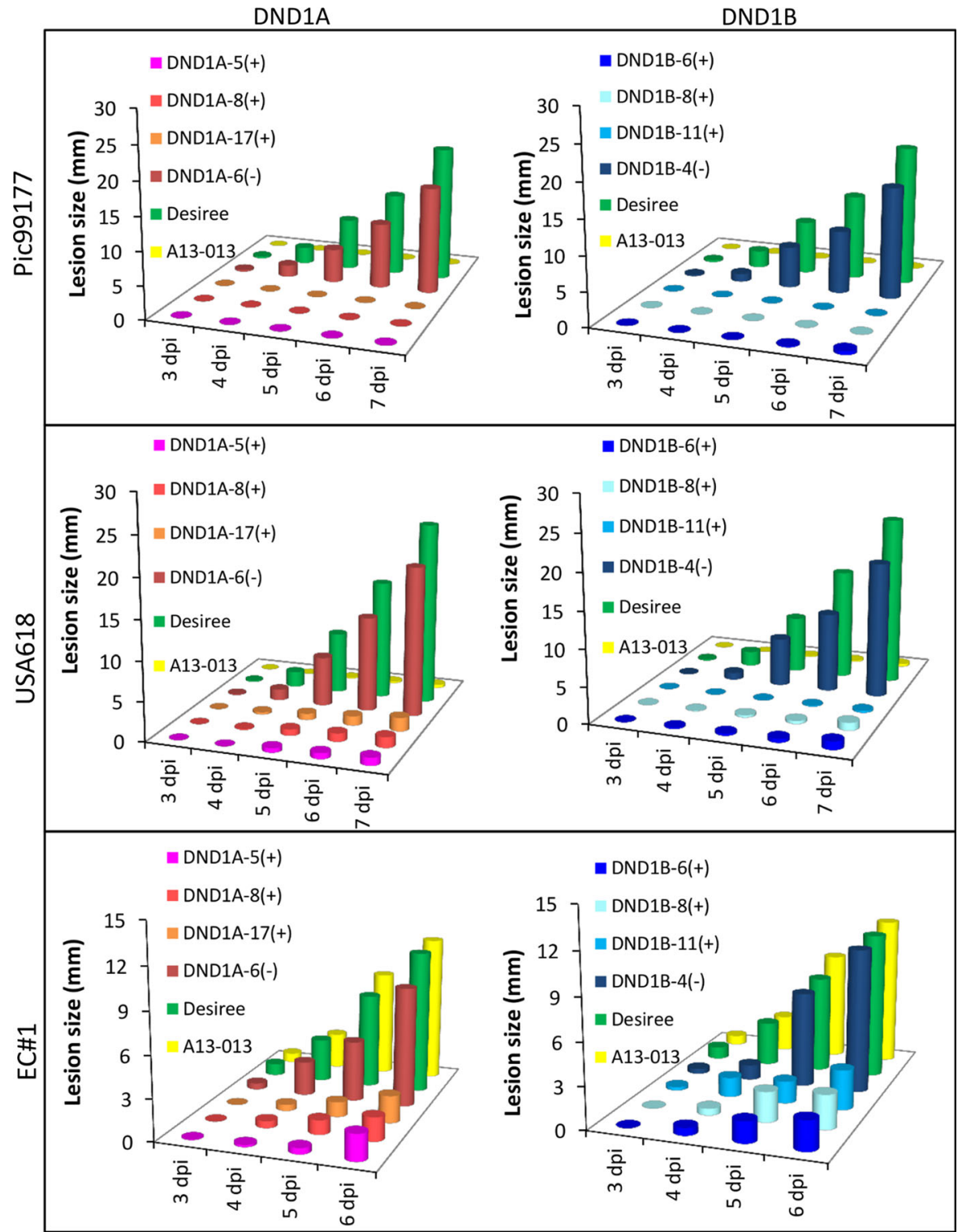

Number of the days post infection(dpi)

potato StDND1-silenced transformants were grown in a screen cage under outdoor conditions the plants looked healthy. Only after 3 months, very small autonecrotic spots developed on the older leaves (Supplementary Fig. 8).

Expression of defense-related gene StPR1 in DND1-silenced potato

In the Arabidopsis dndl mutant an elevated level of salicylic acid (SA) and a constitutively high expression level of PRI (pathogenesis related protein 1) have been reported (Clough et al. 2000; Ahn 2007). To gain some insight in the mechanism of resistance in DND1silenced potato transformants transcript levels of StPRI were monitored in Desiree and the DNDI transformants by qRT-PCR. First, the expression level was measured in all eight potato transformants studied without pathogen infection. All six well-silenced transformants $(+)$ showed a high constitutive expression level compared with Desiree, while the weaksilenced transformants (-) showed the same low level 

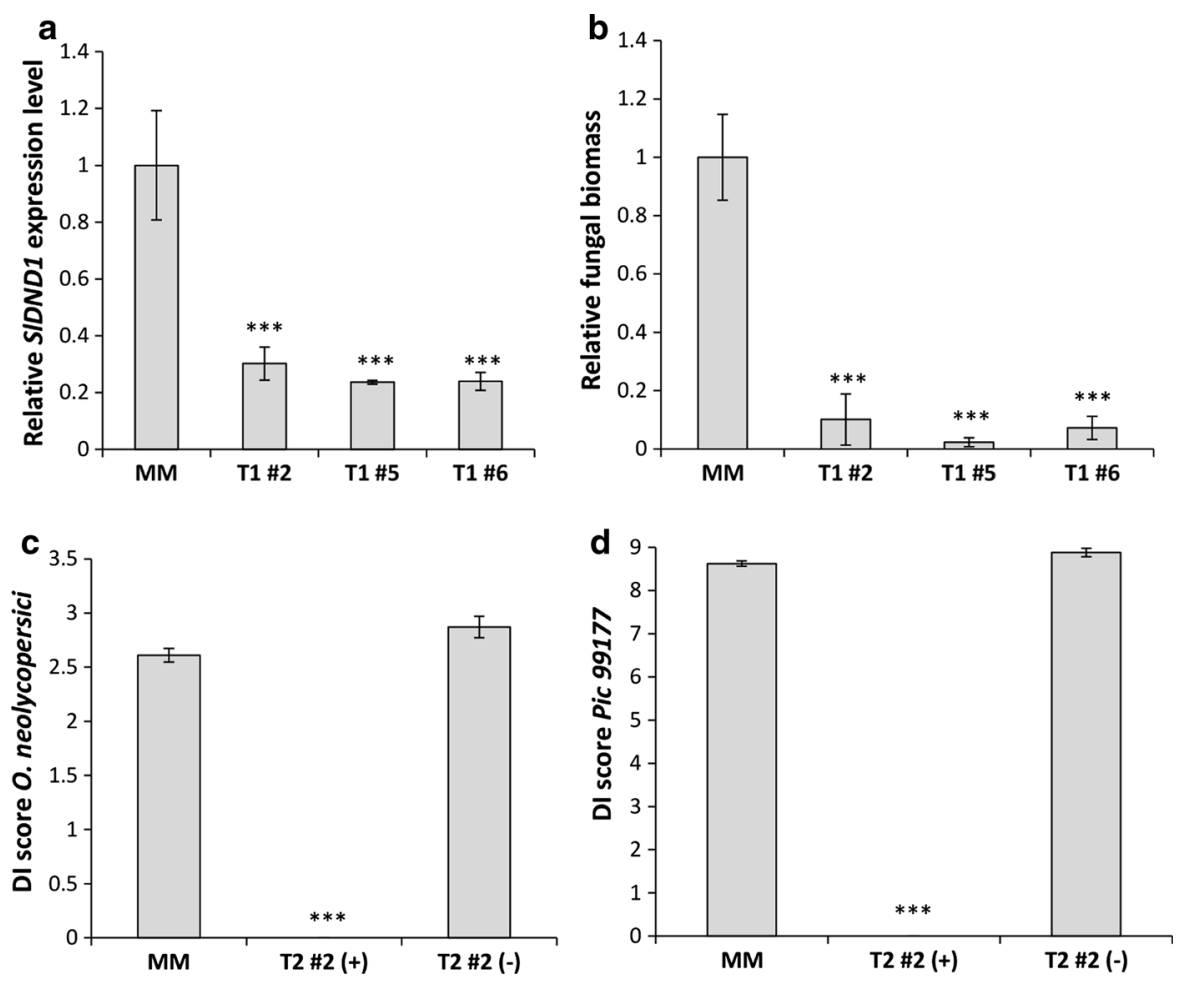

Fig. 4 Powdery mildew and late blight resistance in tomato by impairment of SIDND1. a Relative SIDND1 transcript levels in plants of untransformed cultivar Moneymaker (MM) and three independent T1 plants (T1 \#2, \#5 and \#6) transformed with a silencing construct specifically targeting SIDND1. b Relative fungal biomass of Oidium neolycopersici on MM and the three T1 Plants in a measured 9 days post inoculation (dpi). c Disease index (DI) scores of T2 progeny (T2\#2 family derived from T1\#2) harbouring a SIDND1 silencing construct $(+, \mathrm{n}=13)$ or not $(-, \mathrm{n}=1)$ at $10 \mathrm{dpi}$ with $O$. neolycopersici. DI scores range from 0 (resistant) to 3 (susceptible). d DI scores of the same

of expression as Desiree (Supplementary Fig. 9a). Next, the influence of inoculation with $P$. infestans on StPRl expression level was measured in three selected transformants; two well-silenced $(+)$ and one weaksilenced (-) transformant compared with Desiree. Expression was measured in both mock-inoculated and $P$. infestans-inoculated leaves. As is shown in Supplementary Fig. 9b the expression of StPR1 was highly up-regulated 6 days after $P$. infestans inoculaton in both the transformants and Desiree. However, the level of expression was significantly higher in DND1 well-silenced (+) transformants compared with Desiree and weak-silenced (-) transformants. Thus, both the constitutive and the pathogen-induced level of expression of StPRl was increased after silencing StDND1.

plants as in c but inoculated with Phytophthora infestans isolate Pic99177. DI scores range from 0 (resistant) to 9 (susceptible) and represent a mean of five leaflets of the 3rd leaf (from the bottom) per plant. After harvesting the 3rd leaf for testing with $P$. infestans, the same plant was then inoculated with $O$. neolycopersici. For both powdery mildew and late blight, a significant reduction in DI scores was observed on the T2 plants harbouring a silencing construct $(+)$ compared to plants of MM and T2 plants not harbouring a silencing construct (-). Asterisks indicate degree of significance compared to $\mathrm{MM}$ $(* * * p<0.001)$

\section{Discussion}

Loss of susceptibility factor as an alternative disease resistance type

To combat $P$. infestans, a highly flexible pathogenic oomycete, it is important to identify new types of resistance, in addition to the classical $R$ gene-based resistance (Vleeshouwers et al. 2008). Recessive resistance, not associated with HR reaction, is widely used in crops to provide resistance against viruses, such as resistance to $P V Y$ in pepper or to Bymoviruses in barley (e.g. barley yellow mosaic virus and barley mild mosaic virus) (Ruffel et al. 2002; Stein et al. 2005). Recently, this kind of resistance was also reported against other pathogens, such as the recessive 


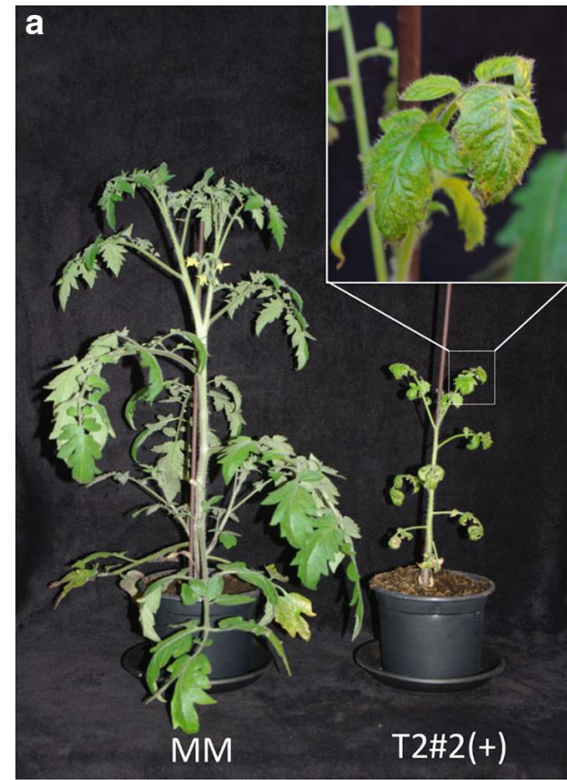

Fig. 5 Morphological alterations observed on tomato and potato by impairment of $D N D 1$ orthologs. a Picture of tomato cultivar Moneymaker (MM) compared to SIDND1-silenced MM transformant T2\#2(+). Both plants were five weeks old. The T2\#2(+) plant shows a dwarf phenotype and autonecrotic

resistance alleles $r k l$ and $r h g l$ against root-knot nematodes in cowpea and cyst nematodes in soybean, respectively (Das et al. 2008; Afzal et al. 2009). The observation in Arabidopsis that loss-of-function mutations in many more $S$ genes can lead to resistance to pathogens is remarkable. Evidence is accumulating that the susceptibility function of these Arabidopsis $S$ genes is conserved across plant species. For example, down regulation of orthologs of PMR4 and $M L O$ leads to powdery mildew resistance in tomato (Bai et al. 2008; Huibers et al. 2013). More surprisingly, resistance resulting after silencing of orthologs of these Arabidopsis $S$ genes in most cases appears to be effective against a wide range of pathogens. For example, the Arabidopsis dmrl gene was originally identified in a screen for resistance to downy mildew caused by $H$. parasitica, and silencing the tomato ortholog resulted in powdery mildew resistance (Huibers et al. 2013). The Arabidopsis dndl mutant was previously reported to be resistant to bacterial, fungal and viral diseases (Yu et al. 1998). In this study, we show for the first time that the DND1 gene can be considered as an $S$ gene for late blight and powdery mildew diseases. It is likely that a susceptibility factor

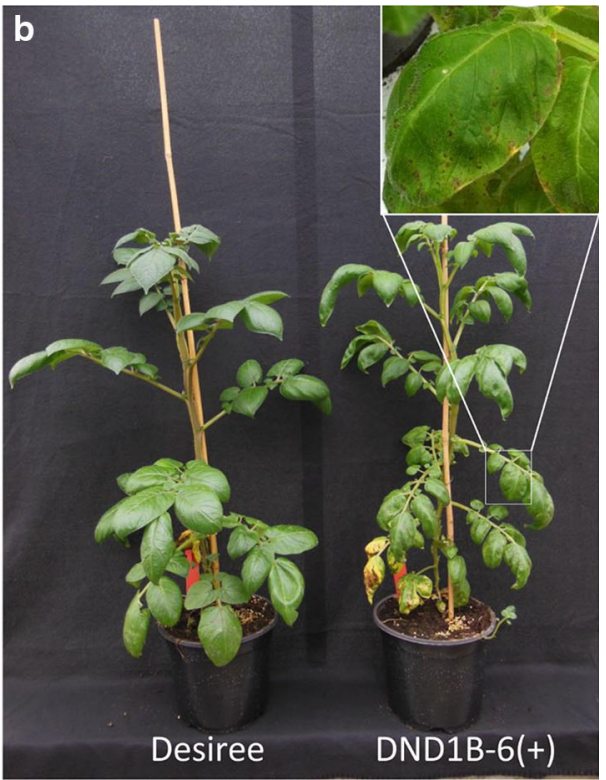

spots on all leaves. b Photo of a potato cultivar Desiree plant compared to StDND1-silenced Desiree transformant DND1B$6(+)$. The DND1B-6(+) plant shows similar growth vigour as Desiree. Autonecrotic spots are visible on older leaves only, not on younger leaves

encoded by $S$ genes is used by multiple pathogens to promote disease development. Therefore, the identified Arabidopsis $S$ genes can be tested in crops to achieve broad-spectrum resistance via loss-of-function mutations and/or RNAi technique. Both approaches are possible in self-fertilizing diploid crops like tomato, while, in tetraploid potato, RNAi is the most realistic possibility. The advantage of the RNAi approach is that resistance obtained via RNAi silencing behaves as a dominant resistance trait, which is preferable for practical breeding programs especially of polyploid, vegetatively propagated crops. Very recently, it was shown that reduced expression of the putative $S$ gene SYNTAXIN-RELATED1 (StSYRI), an ortholog of AtSYP121/AtPEN1 of Arabidopsis, decreased susceptibility to $P$. infestans in potato via the RNAi approach (Eschen-Lippold et al. 2012a, b).

Fitness costs associated with loss of susceptibility factors can be plant-species dependent

$S$ genes are expected to have important biological functions in plants besides being a susceptibility factor (Pavan et al. 2010). For example, the rice Xal3 gene is 
required for both the growth of $X$. oryzae and for pollen development (Chu et al. 2006). Thus, resistance to pathogens achieved by silencing of $S$ genes is potentially associated with negative side effects on other agronomic traits, as shown by the severe dwarfing and autonecrosis in DNDl-silenced tomato plants (Fig. 5a). Therefore, more phenotypic studies are needed to determine whether loss-of-function of DNDl can lead to plants which are acceptable for agriculture/horticulture. Such plants can then also be used as a new source of resistance in breeding. This resistance is inherited recessively after mutation induction or dominantly after RNAi transformation. Among the StDND1-silenced potato transformants we could already select plants with a good level of resistance combined with an almost normal phenotype in the screen cage (Supplementary Fig. 8a). These transformants were obtained with an RNAi construct containing the strong $35 \mathrm{~S}$ promoter. We will try using a native promoter for the expression of the RNAi construct to investigate whether it is possible to obtain plants with a high level of late blight resistance but without fitness costs.

The phenotypic effects of dwarfing and autonecrosis were also described for the original $d n d l$ mutant in Arabidopsis (Clough et al. 2000). In DND1-silenced tomato plants, it was shown that male fertility was decreased and thus offspring after selfing could not be obtained from all transformants. In Arabidopsis, DND1/CNGC2 has been reported to play a role in flowering timing and fertility (Chaiwongsar et al. 2009; Chin et al. 2013). Fortuna et al. (2015) reported that the role of DND1 in flowering timing is independent from SA accumulation, and independent from its role in pathogen defense. Further investigations are necessary to determine whether disease resistance can be achieved in tomato without reduced fertility by decreased expression level or altered functionality of SIDND1.

Interestingly, a much lower level of autonecrosis was found in DND1-silenced potato plants compared to tomato, although they were obtained using the same silencing constructs. Surprisingly, dwarfing was not observed at all in DND1-silenced potato plants under the tested growth conditions, indicating that the fitness costs associated with loss-of-function of $S$ genes seems to depend on the plant species. One explanation for this apparent difference between tomato and potato could be the higher ploidy level combined with a high level of heterozygosity (multi-allelism) of potato that could provide a better genetic buffer against pleiotropic, multi-genic and multi-allelic effects at expression level than in diploid homozygous tomato (Gebhardt 2013). Alternatively, the fitness costs after knocking-out plant $S$ genes may depend on the crop species, as was shown for the mlo mutation. In both Arabidopsis and barley, mlo mutants showed early senescence, which is however not observed in the natural ol2 mutant of tomato (Bai et al. 2008). Since yield is the final measure of fitness costs, it will be necessary to test StDNDI silenced potato plants in the field under natural environmental conditions.

Mechanisms of dnd1-mediated resistance

The DND1 gene was identified in Arabidopsis with a screen designed to discover additional components of the avrRpt2-RPS2 disease resistance pathway ( $\mathrm{Yu}$ et al. 1998, 2000). Compared to the wild type Col-0, the loss-of-function mutant $d n d l$ displayed an inability to produce a HR in response to avirulent isolates of Pseudomonas syringae pv. glycinea. In addition, the dndl mutant showed reduced growth, a constitutively elevated level of expression of the $P R I$ gene, HR-like spontaneous lesions without pathogen infection, and resistance to unrelated pathogens including $H$. parasitica, Botrytis cinerea (Clough et al. 2000) and Pectobacterium carotovorum (the bacterial agent causing soft rot disease on Korean cabbage, Ahn 2007). It may be argued that $d n d l$-associated autoimmune responses (such as autonecrosis and dwarfing) result in stressed plants, which in turn may enhance resistance to pathogens. However, we have shown that the DNDl-silenced potato transformants show resistance to late blight and powdery mildew, a constitutively elevated level of expression of the StPRI gene and small autonecrotic lesions, but no reduced growth. Furthermore, the severity of autonecrosis in potato was dependent on environmental conditions. This has also been reported for the $d n d 1$ mutant in Arabidopsis (Clough et al. 2000; Moeder et al. 2011). However, we observed that the level of pathogen resistance was not influenced by environmental conditions, at least in the tuber slice assay. In addition, there is evidence showing that defence-related signalling pathways are required for resistance in the $d n d 1$ mutants, but not for autoimmune phenotypes (Clough et al. 2000; Jirage et al. 2001; Jurkowski et al. 2004). Thus, the resistance 
resulting from loss-of-function of DNDl is not necessarily associated with severe autoimmune phenotypes.

The DND1 gene encodes a cyclic nucleotide-gated cation channel (CNGC) belonging to a large family consisting of 20 members in Arabidopsis (Chin et al. 2013). The CNGCs have a role in conducting $\mathrm{Ca}^{2+}$ into plant cells and are involved in various physiological processes (Sherman and Fromm 2009). The precise role of AtCNGC2 (DND1) in plant defence responses remains elusive, although evidence has been obtained that activation of multiple defence pathways are required for the broad-spectrum resistance in $d n d 1$ mutants (Genger et al. 2008; Moeder et al. 2011). For example, the resistance to $P$. syringae and $H$. parasitica in dndl mutants is dependent on SA accumulation (Genger et al. 2008). Further, the PR1 protein has been shown to have inhibitory activity against $P$. infestans (Niderman et al. 1995). Thus, the highly elevated $P R I$ expression in DND1-silenced plants may lead to increased PR1 protein content, which can play an important role in resistance against $P$. infestans. Resistance to B. cinerea could be abolished by disrupting ethylene signalling (Genger et al. 2008). Further experiments are needed to study the resistance mechanisms associated with the resistance to late blight and powdery mildew in $D N D 1$-silenced potato and tomato plants.

Perspectives of S genes for resistance breeding

Deployment of plant $S$ genes in breeding crops with resistance to pathogens and pests is a relatively new approach as proposed by us in 2010 (Pavan et al. 2010). In the past few years, more and more examples have arisen, where resistance can be achieved by altering plant genes that are required by pathogens to establish a compatible interaction with hosts (reviewed in Van Schie and Takken 2014). Here, we show that $d n d 1$, which plays a pivotal role in disease resistance, may be an interesting gene in resistance breeding of crops. Although we observed negative side effects upon gene silencing via RNAi, especially in tomato, it may be possible to minimise these fitness costs by investigating sufficient numbers of RNAi transformation events, by transformation of different genotypes and/or by sexual crossing followed by selection for offspring plants with normal phenotypes in the presence of pathogen resistance. The high level of heterozygosity and multi-allelism in potato could open up the possibility to select for a more favourable genetic background when using this approach. As shown in this study, silencing DND1 resulted in less fitness costs in potato than in tomato (Fig. 5). In diploid crops like tomato, variation in loss-of-function mutations can be obtained by assessing natural mutations and mutations induced by chemical mutagenesis, such as EMS (Emmanuel and Levy 2002; Minoia et al. 2010). In potato, the approach using mutation induction is possible, as earlier shown for the recessive amf mutant with amylose-free starch (Hovenkamp-Hermelink et al. 1987). However, breeding at the tetraploid level with recessive traits is complicated, although it has recently become more realistic by using allele-specific markers. This approach would be much more appropriate after realisation of the method of hybrid seed propagated potato varieties which are based on a cross between self-compatible diploid homozygous parental lines (Lindhout et al. 2011). Nowadays, new techniques are available to enable the discovery and design of superior allele variants, which combine favourable disease resistance levels with no or less detrimental side effects. Such advanced technologies include TILLING (targeting induced local lesions in genomes); site-directed mutagenesis using Zinc-finger nucleases (Colbert et al. 2001), TALEN (Transcription activator-like effector nuclease)-based gene editing for allele design (Lloyd et al. 2005; Li et al. 2012) and CRISPR-/Cas9 (clustered regularly interspaced short palindromic repeats-associated nuclease Cas9) (Belhaj et al. 2013; Xie and Yang. 2013). For example, the TALEN technology was successfully used to edit the rice gene $O s 11 N 3$ for bacterial blight susceptibility resulting in a specific allele altering this $S$ gene function (Li et al. 2012). Combining TALEN and CRISPR-/Cas9 techniques, Wang et al. (2014) simultaneously edited three homeoalleles of the $M L O$ gene in hexaploid wheat providing resistance to powdery mildew. Taken together, these approaches hold substantial promise in defining and deploying altered host $S$ genes for durable resistance in controlling plant diseases (Dangl et al. 2013).

Acknowledgments Tomato work was funded by a grant from the Technological Top Institute Green Genetics, the Netherlands (TTI-GG:2CC038RP) together with Keygene N.V, Syngenta and Rijk Zwaan Breeding B.V. The potato work was funded by a grant from Wageningen University Fund. We thank Christian 
Bachem for critically reading the manuscript, Dirk Jan Huigen and Gerda van Engelenhoven for maintenance of the potato plant material, Ronald Hutten for providing the SH tubers for the nematode experiment, Casper van Schaik for assisting in the nematode experiment and Johan Bucher for excellent help with the Time Lapse Video system.

\section{Compliance with ethical standards}

Conflict of interest The authors declare that they have no conflict of interest.

Open Access This article is distributed under the terms of the Creative Commons Attribution 4.0 International License (http:// creativecommons.org/licenses/by/4.0/), which permits unrestricted use, distribution, and reproduction in any medium, provided you give appropriate credit to the original author(s) and the source, provide a link to the Creative Commons license, and indicate if changes were made.

\section{References}

Afzal AJ, Natarajan A, Saini N, Iqbal MJ, Geisler M, El Shemy HA, Mungur R, Willmitzer L, Lightfoot DA (2009) The nematode resistance allele at the rhgl locus alters the proteome and primary metabolism of soybean roots. Plant Physiol 151:1264-1280

Ahn IP (2007) Disturbance of the $\mathrm{Ca}^{2+} /$ calmodulin-dependent signalling pathway is responsible for the resistance of Arabidopsis dndl against Pectobacterium carotovorum infection. Mol Plant Pathol 8:747-759

Altamiranda EAG, Andreu AB, Daleo GR, Olivieri FP (2008) Effect of $\beta$-aminobutyric acid (BABA) on protection against Phytophthora infestans throughout the potato crop cycle. Austral Plant Pathol 37:421-427

Bai Y, van der Hulst R, Bonnema G, Marcel TC, Meijer-Dekens F, Niks RE, Lindhout P (2005) Tomato defense to Oidium neolycopersici: dominant $\mathrm{Ol}$ genes confer isolate dependent resistance via a different mechanism than recessive ol2. Mol Plant Microbe Interact 18:354-362

Bai Y, Pavan S, Zheng Z, Zappel NF, Reinstädler A, Lotti C, De Giovanni C, Ricciardi L, Lindhout P, Visser R, Theres K, Panstruga R (2008) Naturally occurring broad-spectrum powdery mildew resistance in a Central American tomato accession is caused by loss of mlo function. Mol Plant Microbe Interact 21:30-39

Belhaj K, Chaparro-Garcia A, Kamoun S, Nekrasov V (2013) Plant genome editing made easy: targeted mutagenesis in model and crop plants using the CRISPR/Cas system. Plant Methods 9:39

Bengtsson T, Holefors A, Witzell J, Andreasson E, Lijeroth E (2013) Activation of defence responses to Phytphthora infestans in potato by BABA. Plant Pathol 63:193-202

Büschges R, Hollricher K, Panstruga R, Simons G, Wolter M, Frijters A, van Daelen R, Van der Lee T, Diergaarde P, Groenendijk J, Töpsch S, Vos P, Salamini F, Schulze-Lefert P (1997) The barley Mlo gene: a novel control element of plant pathogen resistance. Cell 88:695-705
Caten CE, Jinks JL (1968) Spontaneous variability of single isolates of Phytophthora infestans I. Cultural variation. Can J Bot 46:329-347

Chaiwongsar S, Strohm AK, Roe JR, Godiwalla RY, Chan CWM (2009) A cyclic nucleotide-gated channel is necessary for optimum fertility in high-calcium environments. New Phytol 183:76-87

Chen LQ, Hou BH, Lalonde S, Takanaga H, Hartung ML, Qu XQ, Guo WJ, Kim JG, Underwood W, Chaudhuri B, Chermak D, Antony G, White FF, Somerville SC, Mudgett MB, Frommer WF (2010) Sugar transporters for intercellular exchange and nutrition of pathogens. Nature 468:527-532

Chin K, DeFalco TA, Moeder W, Yoshioka K (2013) The Arabidopsis cyclic nucleotide-gated ion channels AtCNGC2 and AtCNGC4 work in the same signalling pathway to regulate pathogen defense and floral transition. Plant Physiol 163:611-624

Chu Z, Yuan M, Yao J, Ge X, Yuan B, Xu C, Li X, Fu B, Li Z, Bennetzen JL, Zhang Q, Wang S (2006) Promoter mutations of an essential gene for pollen development result in disease resistance in rice. Genes Dev 20:1250-1255

Clough SJ, Fengler KA, Yu IC, Lippok B, Smith RK, Bent AF (2000) The Arabidopsis dndl "defense, no death" gene encodes a mutated cyclic nucleotide-gated ion channel. Proc Natl Acad Sci USA 97:9323-9328

Colbert T, Till BJ, Tompa R, Reynolds S, Steine MN, Yeung AT, McCallum CM, Camai L, Henikoff S (2001) Highthroughput screening for induced point mutations. Plant Physiol 126:480-484

Dangl JL, Horvath DM, Staskawicz BJ (2013) Pivoting the plant immune system from dissection to deployment. Science 341:746-751

Das S, DeMason DA, Ehlers JD, Close TJ, Roberts PA (2008) Histological characterization of root-knot nematode resistance in cowpea and its relation to reactive oxygen species modulation. J Exp Bot 59:1305-1313

Emmanuel E, Levy AA (2002) Tomato mutants as tools for functional genomics. Curr Opin Plant Biol 5:112-117

Eschen-Lippold L, Altmann S, Rosahl S (2010) DL- $\beta$ aminobutyric acid-induced resistance of potato against Phytophthora infestans requires salicylic acid but not oxylipins. Mol Plant Microbe Interact 23:585-592

Eschen-Lippold L, Lübken T, Smolka U, Rosahl S (2012a) Characterization of potato plants with reduced StSYR1 expression. Plant Signal Behav 7:559-562

Eschen-Lippold L, Landgraf R, Smolka U, Schulze S, Heilmann M, Heilmann I, Hause G, Rosahl S (2012b) Activation of defense against Phytophthora infestans in potato by downregulation of syntaxin gene expression. New Phytol 193:985-996

Fortuna A, Lee J, Ung H, Chin K, Moeder W, Yoshioka K (2015) Crossroads of stress responses, development and flowering regulation - the multiple roles of cyclic nucleotide gated ion channel 2. Plant Signal Behav 10(3):e989758

Foster S, Park TH, Pel M, Brigneti G, Śliwka J, Jagger L, van der Vossen EAG, Jones JDG (2009) Rpi-vnt1.1, a Tm- $2^{2}$ homolog from Solanum venturii, confers resistance to potato late blight. Mol Plant Microbe Interact 22:589-600

Fry WE, Goodwin SB (1997) Resurgence of the Irish potato famine fungus. Bioscience 47:363-371 
Gebhardt C (2013) Bridging the gap between genome analysis and precision breeding in potato. Trends Genet 29:248-256

Genger R, Jurkowski G, McDowell J, Lu H, Jung H, Greenberg J, Bent A (2008) Signaling pathways that regulate the enhanced disease resistance of Arabidopsis "defense, no death" mutants. Mol Plant Microbe Interact 21:1285-1296

Haverkort AJ, Boonekamp PM, Hutten R, Jacobsen E, Lotz LAP, Kessel GJT, Visser RGF, van der Vossen EAG (2008) Societal costs of late blight in potato and prospects of durable resistance through cisgenic modification. Potato Res 51:47-57

Helliwell C, Waterhouse P (2003) Constructs and methods for high-throughput gene silencing in plants. Methods 30:289-295

Hovenkamp-Hermelink JHM, Jacobsen E, Ponstein AS, Visser RGF, Vos-Scheperkeuter GH, Bijmolt EW, de Vries JN, Witholt B, Feenstra WJ (1987) Isolation of an amylose-free starch mutant of the potato (Solanum tuberosum L.). Theor Appl Genet 75:217-221

Hückelhoven R, Eichmann R, Weis C, Hoefle C, Proels RK (2013) Genetic loss of susceptibility: A costly route to disease resistance? Plant Pathol 62:56-62

Huibers RP, Loonen AEHM, Gao D, Van den Ackerveken G, Visser RGF, Bai Y (2013) Powdery mildew resistance in tomato by impairment of SIPMR4 and SIDMR1. PLoS ONE 8:e67467

Humphry M, Consonni C, Panstruga R (2006) Mlo-based powdery mildew immunity: Silver bullet or simply nonhost resistance? Mol Plant Pathol 7:605-610

Jirage D, Zhou N, Cooper B, Clarke JD, Dong X, Glazebrook J (2001) Constitutive salicylic acid-dependent signaling in cpr1 and cpr6 mutants requires PAD4. Plant J 26:395-407

Jo KR, Arens M, Kim TY, Jongsma MA, Visser RGF, Jacobsen E, Vossen JH (2011) Mapping of the $S$. demissum late blight resistance gene $R 8$ to a new locus on chromosome IX. Theor Appl Genet 123:1331-1340

Jurkowski GI, Smith RK Jr, Yu IC, Ham JH, Sharma SB, Klessig DF, Fengler KA, Bent AF (2004) Arabidopsis DND2, a second cyclic nucleotide-gated ion channel gene for which mutation causes the "Defense, No Death" phenotype. Mol Plant Microbe Interact 17:511-520

Kim DS, Hwang BK (2012) The pepper $M L O$ gene, CaMLO2, is involved in the susceptibility cell-death response and bacterial and oomycete proliferation. Plant J 72:843-855

Li T, Liu B, Spalding MH, Weeks DP, Yang B (2012) Highefficiency TALEN-based gene editing produces diseaseresistant rice. Nat Biotechnol 30:390-392

Lindhout P, Meijer D, Schotte T, Hutten RC, van Visser RGF, Eck HJ (2011) Towards F1 hybrid seed potato breeding. Potato Res 54:301-312

Livak KJ, Schmittgen TD (2001) Analysis of relative gene expression data using real-time quantitative PCR and the $2^{-\Delta \Delta C T}$ method. Methods 25:402-408

Lloyd A, Plaisier CL, Carroll D, Drews GN (2005) Targeted mutagenesis using zinc-finger nucleases in Arabidopsis. Proc Natl Acad Sci USA 102:2232-2237

Lokossou AA, Rietman H, Wang M, Krenek P, van der Schoot H, Henken B, Hoekstra R, Vleeshouwers VGAA, van der Vossen EAG, Visser RGF, Jacobsen E, Vosman B (2010) Diversity, distribution, and evolution of Solanum bulbocastanum late blight resistance genes. Mol Plant Microbe Interact 23:1206-1216

Lyngkjaer MF, Newton AC, Atzema JL, Baker SJ (2000) The barley mlo-gene: an important powdery mildew resistance source. Agronomie 20:745-756

Malcolmson JF (1969) Races of Phytophthora infestans occurring in Great Britain. Trans $\mathrm{Br}$ Mycol Soc 53:417-423

McDowell JM, Williams SG, Funderburg NT, Eulgem T, Dangl JL (2005) Genetic analysis of developmentally regulated resistance to downy mildew (Hyaloperonospora parasitica) in Arabidopsis thaliana. Mol Plant Microbe Interact 18:1226-1234

Minoia S, Petrozza A, D’ Onofrio O, Piron F, Mosca G, Sozio G, Cellini F, Bendahmane A, Carriero F (2010) A new mutant genetic resource for tomato crop improvement by TILLING technology. BMC Res Notes 3:69

Moeder W, Urquhart W, Ung H, Yoshioka K (2011) The role of cyclic nucleotide-gated ion channels in plant immunity. Mol Plant 4:442-452

Niderman T, Genetet I, Bruyère T, Gees R, Stintzi A, Legrand M, Fritig B, Mösinger E (1995) Pathogenesis-related PR-1 proteins are antifungal. Isolation and characterization of three 14-kilodalton proteins of tomato and of a basic PR-1 of tobacco with inhibitory activity against Phytophthora infestans. Plant Physiol 108:17-27

Pavan S, Jacobsen E, Visser RGF, Bai Y (2010) Loss of susceptibility as a novel breeding strategy for durable and broad-spectrum resistance. Mol Breed 25:1-12

Pavan S, Schiavulli A, Appiano M, Marcotrigiano AR, Cillo F, Visser RGF, Bai Y, Lotti C, Ricciardi L (2011) Pea powdery mildew erl resistance is associated to loss-of-function mutations at a $M L O$ homologous locus. Theor Appl Genet 123:1425-1431

Pel MA, Foster SJ, Park TH, Rietman H, van Arkel G, Jones JDG, Van Eck HJ, Jacobsen E, Visser RGF, Van der Vossen EAG (2009) Mapping and cloning of late blight resistance genes from Solanum venturii using an interspecific candidate gene approach. Mol Plant Microbe Interact 22:601-615

Rouppe van der Voort J, Wolters P, Folkertsma R, Hutten R, van Zandvoort P, Vinke H, Kanyuka K, Bendahmane A, Jacobsen E, Janssen R, Bakker J (1997) Mapping of the cyst nematode resistance locus Gpa2 in potato using a strategy based on comigrating AFLP markers. Theor Appl Genet 95:874-880

Ruffel S, Dussault MH, Palloix A, Moury B, Bendahmane A, Robaglia C, Caranta C (2002) A natural recessive resistance gene against potato virus $Y$ in pepper corresponds to the eukaryotic initiation factor 4E (eIF4E). Plant J 32:1067-1075

Saitou N, Nei M (1987) The neighbor-joining method: a new method for reconstructing phylogenetic trees. Mol Biol Evol 4:406-425

Schouten HJ, Krens FA, Jacobsen E (2006) Cisgenic plants are similar to traditionally bred plants. EMBO Rep 7:750-753

Sherman T, Fromm H (2009) Physiological roles of cyclic nucleotide gated channels in plants. In: Baluška F, Mancuso $\mathrm{S}$ (eds) Signaling in plants, signalling and communication in plants. Springer, Berlin, pp 91-106 
Stein N, Perovic D, Kumlehn J, Pellio B, Stracke S, Streng S, Ordon F, Graner A (2005) The eukaryotic translation initiation factor $4 \mathrm{E}$ confers multiallelic recessive Bymovirus resistance in Hordeum vulgare (L.). Plant J 42:912-922

Tamura K, Dudley J, Nei M, Kumar S (2007) MEGA4: molecular evolutionary genetics analysis (MEGA) software version 4.0. Mol Biol Evol 24:1596-1599

Uchida E, Rozelle S, Xu J (2009) Conservation payments, liquidity constraints and off-farm labor: impact of the Grain for Green program on rural households in China. Am J Agric Econ 91:70-86

Van Bezooijen J (2006) Methods and techniques for nematology. Wageningen University, Wageningen

Van den Heuvel JFJM, Peters D (1989) Improved detection of potato leafroll virus in plant material and in aphids. Phytopathology 79:963-967

Van Schie C, Takken F (2014) Susceptibility genes 101: how to be a good host. Annu Rev Phytopathol 52:551-581

Visser RGF (1991) Transformation of potato. In: Lindsey K (ed) Plant tissue culture manual, vol B5. Kluwer Academic Publishers, Dordrecht, pp 1-9

Vleeshouwers VGAA, van Dooijeweert W, Keizer LCP, Sijpkes L, Govers F, Colon LT (1999) A laboratory assay for Phytophthora infestans resistance in various Solanum species reflects the field situation. Eur J Plant Pathol 105:241-250

Vleeshouwers VGAA, Rietman H, Krenek P, Champouret N, Young C, Oh S-K, Wang M, Bouwmeester K, Vosman B, Visser RGF, Jacobsen E, Govers F, Kamoun S, Van der Vossen EAG (2008) Effector genomics accelerates discovery and functional profiling of potato disease resistance and Phytophthora infestans avirulence genes. PLoS ONE 3:e2875

Vleeshouwers VGAA, Raffaele S, Vossen JH, Champouret N, Oliva R, Segretin ME, Rietman H, Cano LM, Lokossou A, Kessel G, Pel MA, Kamoun S (2011) Understanding and exploiting late blight resistance in the age of effectors. Annu Rev Phytopathol 49:507-531

Vogel JP, Somerville SC (2000) Isolation and characterization of powdery mildew-resistant Arabidopsis mutants. Proc Natl Acad Sci USA 97:1897-1902

Vogel JP, Raab TK, Schiff C, Somerville SC (2002) PMR6, a pectate lyase-like gene required for powdery mildew susceptibility in Arabidopsis. Plant Cell 14:2095-2106
Vossen JH, Nijenhuis M, Arens-De Reuver MJB, van der Vossen EAG, Jacobsen E, Visser RGF (2011) Cloning and exploitation of a functional $R$ gene from Solanum chacoense. Patent number WO/2011/034433. http://patentscope.wipo. int/search/en/detail.jsf?docId=WO2011034433\&recNum= $50 \&$ docAn $=$ NL2010050612 \&queryString $=$ nik $\& \max R e c=$ 888

Wang Y, Cheng X, Shan Q, Zhang Y, Liu J, Gao C, Qiu J (2014) Simultaneous editing of three homoeoalleles in hexaploid bread wheat confers heritable resistance to powdery mildew. Nature Biotechnol 32:947-951

Wastie RL (1991) Breeding for resistance. In: Ingram DS, Williams DS (eds) Phytophthora infestans, the cause of late blight of potato. Advances in plant pathology, vol 7. Academic Press Ltd, London, pp 193-224

Waterhouse PM, Helliwell CA (2003) Exploring plant genomes by RNA-induced gene silencing. Nat Rev Genet 4:29-38

White T, Bruns T, Lee S, Taylor J (1990) Amplification and direct sequencing of fungal ribosomal RNA genes for phylogenetics. In: Innis MA, Gelfand DH, Sninsky JJ, White TJ (eds) PCR protocols: a guide to methods and applications. Academic Press Inc., San Diego, pp 315-322

Xie K, Yang Y (2013) RNA-guided genome editing in plants using a CRISPR-Cas system. Mol Plant 6:1975-1983

Yu IC, Parker J, Bent AF (1998) Gene-for-gene disease resistance without the hypersensitive response in Arabidopsis dnd1 mutant. Proc Natl Acad Sci USA 95:7819-7824

Yu IC, Fengler KA, Clough SJ, Bent AF (2000) Identification of Arabidopsis mutants exhibiting an altered hypersensitive response in gene-for-gene disease resistance. Mol Plant Microbe Interact 13:277-286

Zheng Z, Nonomura T, Appiano M, Pavan S, Matsuda Y, Toyoda H, Wolters AMA, Bai Y (2013) Loss of function in Mlo orthologs reduces susceptibility of pepper and tomato to powdery mildew disease caused by Leveillula taurica. PLoS ONE 8:e70723

Zhu S, Li Y, Vossen JH, Visser RGF, Jacobsen E (2012) Functional stacking of three resistance genes against $P h y$ tophthora infestans in potato. Transgenic Res 21:89-99 